\title{
PENGEMBANGAN E-MODUL MATERI MOMENTUM DAN IMPULS BERBASIS PROCESS ORIENTED GUIDED INQUIRY LEARNING (POGIL) UNTUK MENINGKATKAN KEMAMPUAN BERPIKIR TINGKAT TINGGI SISWA SMA KELAS $X$
}

\author{
Yasmine Maya Savira $^{\text {a)}}$, Agus Setyo Budi ${ }^{\text {b) }}$, Yetti Supriyatic) \\ Program Studi Pendidikan Fisika, Fakultas Matematika dan Ilmu Pengetahuan Alam, Universitas Negeri Jakarta, \\ Jl. Rawamangun Muka No. 1 DKI Jakarta, Indonesia, 13220 \\ Email: a)yasminemayasavira@gmail.com, b)abihuda123@yahoo.com, ${ }^{c}$ y_supriyati@yahoo.com
}

\begin{abstract}
Abstrak
Penelitian ini bertujuan untuk mengembangkan e-modul materi momentum dan impuls berbasis Process Oriented Guided Inquiry Learning (POGIL) yang dilengkapi dengan soal-soal HOTS untuk meningkatkan kemampuan berpikir tingkat tinggi siswa SMA kelas X. Metode yang digunakan dalam penelitian ini adalah metode research and development (R\&D) dengan model pengembangan ADDIE. Model pengembangan ADDIE meliputi lima tahapan, yaitu tahap analisis (Analyze), tahap perencanaan (Design), tahap pengembangan (Development), tahap implementasi (Implementation), dan tahap evaluasi (Evaluate). Produk dibuat menggunakan software 3D Pageflip Professional 1.7.7. Penilaian angket uji validasi diinterpretasikan dengan Skala Likert. Hasil uji validasi oleh ahli materi diperoleh $82.78 \%$ dengan kategori sangat layak, hasil uji validasi oleh ahli media diperoleh $88.81 \%$ dengan kategori sangat layak, dan hasil uji validasi oleh ahli pembelajaran diperoleh $80.83 \%$ dengan kategori sangat layak. Hasil uji coba lapangan oleh guru fisika SMA kelas X dan XI diperoleh 98.25\% dengan kategori sangat layak dan hasil uji coba lapangan oleh siswa diperoleh $92.05 \%$ dengan kategori sangat layak. Uji coba lapangan kepada 36 siswa kelas XI MIPA 2 SMAN 44 Jakarta diperoleh hasil rata-rata nilai pre-test sebesar 35.00 dan post-test sebesar 66.25. Hasil yang diperoleh pada uji Gain sebesar 0.485 dengan klasifikasi sedang. Berdasarkan hasil uji validasi dan uji coba lapangan, dapat disimpulkan bahwa produk yang dikembangkan telah layak digunakan sebagai bahan ajar mandiri untuk meningkatkan kemampuan berpikir tingkat tinggi siswa pada materi momentum dan impuls.
\end{abstract}

Kata Kunci: E-modul, Momentum dan Impuls, POGIL, HOTS, Bahan ajar, 3D PageFlip

\begin{abstract}
This research aims to development of e-module for momentum and impulse materials based on Process Oriented Guided Inquiry Learning (POGIL) that is equipped with HOTS questions to improve high order thinking skills for Senior High School Students in Class X. The method used in this research is method of research and development (R\&D) with the ADDIE development model. The ADDIE development model includes five stages, there are the analysis stage (Analyze), the planning stage (Design), the development stage (Development), the implementation (Implemetation), and evaluation stage (Evaluate). This product is made using 3D Pageflip Professional 1.7.7. Assessment of questionnaire validation test instrument is interpreted by using Likert Scale. The result of validation test by material experts obtained $82.78 \%$ with a very decent category, the result of validation test by media experts
\end{abstract}

Seminar Nasional Fisika 2019

Prodi Pendidikan Fisika dan Fisika, Fakultas MIPA, Universitas Negeri Jakarta 
obtained $88.81 \%$ with a very decent category, and the result of validation test by education experts obtained $80.83 \%$ with a very decent category. The result of field trial test by high school physic teachers Class X and XI obtained $98.25 \%$ with a very decent category and the result of field trial by students obtained $92.05 \%$ with a very decent category. The result of field trials test by 36 students of Class XI MIPA 2 of SMAN 44 Jakarta obtained an average of pre-test score 35.00 and an average of post-test score 66.25. the result of Gain test obtained 0.485 . in the medium classification. Based on the results of validation test and field trials test, it can be concluded that the developed product has been used as an independent teaching material to improve students High Order Thinking Skills in momentum and impulse materials.

Keywords: E-module, momentum and impulse, POGIL, HOTS, teaching material, 3D PageFlip

\section{PENDAHULUAN}

Kurikulum 2013 menekankan pada pembelajaran berbasis teknologi sesuai dengan Peraturan Menteri Pendidikan dan Kebudayaan Nomor 69 Tahun 2013 tentang kerangka dasar dan struktur kurikulum Sekolah Menengah Atas (SMA) atau Madrasah Aliyah (MA), bahwa secara umum kurikulum 2013 dikembangkan berdasarkan tiga faktor yaitu faktor tantangan internal, faktor tantangan eksternal, dan faktor penyempurnaan pola pikir. Untuk faktor tantangan eksternal berkaitan dengan ICT (teknologi informasi dan komunikasi) yang berkembang cepat hingga berpengaruh ke dalam dunia pendidikan yang tidak terlepas dari penggunaan berbantuan teknologi dalam kegiatan pembelajaran [1].

Pembelajaran berbasis teknologi pada kurikulum 2013 diharapkan mampu menjadikan proses pembelajaran lebih menyenangkan sehingga menumbuhkan ketertarikan peserta didik dalam belajar, membantu pemahaman peserta didik, memotivasi peserta didik, dan membuat proses pembelajaran berpusat pada peserta didik. Khusunya dalam pelajaran fisika, diharapkan pembelajaran berbasis teknologi dapat membantu pemahaman dan penguasaan konsep peserta didik. Hal ini dikarenakan pokok bahasan dalam pembelajaran fisika terdiri dari teori, hukum, postulat dan persamaan matematis yang memiliki karakteristik tersendiri [2].

Kurikulum 2013 menuntut guru untuk melakukan pembelajaran yang dapat mendorong peserta didik untuk berpikir kritis dan memiliki kemampuan berpikir tingkat tinggi, sehingga siswa tidak hanya mampu untuk mengingat, memahami, dan mengaplikasikan. Namun, pada kenyataannya bahan ajar yang digunakan dalam kegiatan pembelajaran belum memuat soal-soal yang dapat melatih peserta didik untuk berpikir tingkat tinggi. Berdasarkan analisis kebutuhan yang dilakukan di SMAN 44 Jakarta didapatkan bahwa berbahwa 100\% guru menyatakan bahwa buku fisika yang digunakan saat ini belum memuat soalsoal untuk meningkatkan kemampuan berpikir tingkat tinggi peserta didik dan $88.64 \%$ peserta menyatakan bahwa buku fisika yang digunakan saat ini belum memuat soal-soal untuk meningkatkan kemampuan berpikir tingkat tinggi.

Teknologi multimedia merupakan salah satu upaya dalam era teknologi informasi untuk menumbuhkan ketertarikan siswa dalam proses pembelajaran, hal ini dikarenakan aplikasi multimedia dalam pembelajaran dapat menyajikan konsep dan keterampilan tingkat tinggi dalam pembelajaran, yang memiliki keterkaitan antar satu unsur dengan unsur lainnya yang tidak cukup diajarkan melalui buku semata. Aplikasi multimedia interaktif dalam pembelajaran dapat menjelaskan suatu konsep dengan menggali konsep yang termuat dalam suatu materi yang dihadapinya, sehingga dapat relatif lebih cepat membangun pemahaman siswa untuk bereskplorasi dan menggali konsep yang termuat dalam suatu materi yang dihadapinya karena terintegrasi komponen-komponen seperti teks, animasi, gambar, dan video [3].

Penguasaan konsep yang diperoleh dari multimedia interaktif dalam pembelajaran dapat membantu melatih keterampilan berpikir tingkat tinggi. Untuk mengembangkan multimedia dalam proses pembelajaran dibutuhkan suatu kreativitas pendidik dalam merancang bahan ajar yang akan digunakan dalam proses belajar. Bahan ajar memiliki peranan penting sebagai sarana untuk mencapai tujuan pembelajaran dan tuntutan kompetensi [4]. Namun bahan ajar di sekolah masih memiliki kelemahan yaitu penyampaian isi dalam bahan ajar tidak terstruktur dengan baik dan kemasan kurang menarik [5].

Seminar Nasional Fisika 2019

Prodi Pendidikan Fisika dan Fisika, Fakultas MIPA, Universitas Negeri Jakarta 
Berdasarkan analisis kebutuhan yang dilakukan di kelas X MIPA SMAN 44 Jakarta terhadap 44 responden didapatkan bahwa $95.45 \%$ buku fisika yang digunakan saat ini kurang menarik dan membosankan selain itu $90.91 \%$ buku fisika yang digunakan terkesan monoton, dan $88.64 \%$ materi yang disajikan pada buku fisika yang digunakan sulit dipahami. Hal ini menyebabkan siswa sulit untuk melakukan pembelajaran mandiri, untuk itu dibutuhkan bahan ajar mandiri berupa modul, dimana karakteristik modul menekankan siswa belajar mandiri. Seiring dengan perkembangan ilmu pengetahuan dan teknologi, bahan ajar bukan hanya dalam bentuk bahan ajar cetak, akan tetapi dapat berbentuk bahan ajar interaktif salah satunya modul elektronik [6], dimana modul elektronik ini dapat membantu siswa mempelajari materi dan konsep fisika, memudahkan siswa dalam memahami materi, pembelajaran menjadi menarik, interaktif, dan pembelajaran semakin efisien. Modul elektronik merupakan bahan ajar mandiri bagi peserta didik yang disusun secara sistematis dan interaktif, disajikan dalam format elektronik, dimana setiap kegiatan pembelajaran didalamnya dihubungkan dengan tautan (link) sebagai navigasi yang membuat peserta didik menjadi lebih interaktif dengan program yang dilengkapi dengan video, audio, animasi, dan kuis [7]. Selain itu, dengan menggunakan modul elektonik siswa dapat mempelajari materi dengan mudah dan membantu siswa dalam mencapai kompetensi yang diharapkan [8]. Berdasarkan analisis kebutuhan yang dilakukan di SMAN 44 Jakarta didapatkan bahwa $95.45 \%$ siswa tertarik belajar fisika menggunakan bahan ajar berupa modul elektronik, 95.45\% siswa memerlukan bahan ajar yang dapat digunakan sebagai penunjang pembelajaran mandiri dan $88.64 \%$ siswa membutuhkan modul elektronik yang memuat soal-soal untuk meningkatkan kemampuan berpikir tingkat tinggi.

Penggunaan modul elektronik sebagai bahan ajar mandiri ini didukung dengan analisis kebutuhan yang dilakukan di SMAN 44 Jakarta didapatkan bahwa 100\% siswa mempunyai fasilitas teknologi sebagai penunjang pembelajaran mandiri. Proses pembelajaran dengan modul elektronik membuat siswa tidak lagi bergantung pada instruktur sebagai satu-satunya sumber informasi, sehingga terciptanya pembelajaran interaktif dan berpusat pada siswa dan menempatkan guru sebagai fasilitator kegiatan belajar dan membantu siswa memahami tujuan pembelajaran seperti tuntutan Kurikulum 2013.

Analisis kebutuhan yang dilakukan kepada 44 responden kelas X MIPA di SMA Negeri 44 Jakarta didapatkan bahwa $90.91 \%$ siswa mengalami kesulitan dalam memahami materi fisika, khusunya pada materi momentum dan impuls dan $95.45 \%$ siswa membutuhkan modul elektronik pada pokok bahasan momentum dan impuls yang dilengkapi dengan gambar, animasi dan video. Berdasarkan analisis tersebut, maka dipilihlah materi momentum dan impuls. Konsep momentum dan impuls termasuk dalam konsepkonsep yang fenomenanya cenderung abstrak dan konsep momentum dan impuls dianggap sederhana padahal sebenarnya merupakan konsep yang kompleks Sekercioglu dan Kocakula, 2008. Hal ini senada dengan pendapat [9], dimana momentum, impuls, dan tumbukan terjadi dalam waktu yang sangat singkat dan cepat. Materi yang bersifat abstrak ini mengakibatkan siswa kesulitan untuk menelaah konsep momentum [10]. Dalam penyelesaian persoalan pada materi momentum dan impuls tidak cukup dengan mengandalkan kemampuan mengingat atau menghafal rumus-rumus dan konsep [11]. Pendapat tersebut didukung oleh penelitian Agustin [12], dimana 17 dari 34 siswa yang mengalami kesalahan dalam pemecahan masalah pada konsep momentum; 29 siswa mengalami kesalahan dalam pemecahan masalah pada konsep impuls; 26 siswa yang mengalami kesalahan dalam pemecahan masalah pada hukum kekekalan momentum; 24 siswa yang mengalami kesalahan dalam pemecahan masalah pada konsep tumbukan.

Dalam proses pembelajaran, selain pentingnya penggunaan bahan ajar, model pembelajaran merupakan komponen penting penunjang tercapainya tujuan pembelajaran, pemilihan model pembelajaran memberikan pengaruh pada proses tercapainya tujuan pembelajaran [13]. Adapun model pembelajaran yang dipilih adalah model pembelajaran POGIL, dimana model pembelajaran POGIL merupakan pembelajaran yang berorientasi proses yang berpusat pada peserta didik, mendorong peserta didik mengolah informasi dan pengetahuan, dan membantu peserta didik dalam mengembangkan pemahaman dengan menerapkan learning cycle dalam aktivitas inkuiri terbimbing [14]. siklus pembelajaran dalam model pogil terdiri dari empat tahap yaitu: (1) tahap orientasi, (2) tahap eksplorasi, (3) tahap pembentukan konsep, dan (4) tahap aplikasi. Process Oriented Guided Inquiry Learning (POGIL) merupakan model

Seminar Nasional Fisika 2019

Prodi Pendidikan Fisika dan Fisika, Fakultas MIPA, Universitas Negeri Jakarta 
pembelajaran yang menekankan pada komponen proses dan komponen isi dari pembelajaran, dimana komponen proses meliputi bagaimana menerima, mengaplikasikan, dan menghasilkan pengetahuan, dimana Komponen proses ditekankan untuk mengembangkan kemampuan berpikir siswa dalam memahami materi pelajaran [15].

Berdasarkan penelitian yang berjudul "Pengembangan E-Module Kimia Berbasis POGIL (Process Oriented Guided Inquiry Learning) Pada Materi Reduksi-Oksidasi Sebagai Sumber Belajar Siswa", menunjukkan bahwa e-module yang dikembangkan sangat baik dan sudah layak digunakan dalam proses pembelajaran dan dapat dijadikan sebagai sumber belajar mandiri siswa, dimana hasil validasi e-module reaksi redoks oleh ahli materi, bahasa, dan media menunjukkan persentase capaian sebesar $90 \%$, hasil uji coba e-module reaksi redoks oleh guru menunjukkan persentase capaian sebesar $80 \%$, dan hasil uji coba e-module reaksi redoks oleh siswa menunjukkan persentase capaian sebesar 87,67\%. penilaian dari para ahli, uji coba pada siswa, dan guru secara keseluruhan memiliki interpretasi baik sekali [16].

Berdasarkan uraian di atas, perlu dilakukan penelitian dengan judul "Pengembangan E-Modul Materi Momentum dan Impuls Berbasis Process Oriented Guided Inquiry Learning (POGIL) Untuk Meningkatkan kemampuan berpikir tingkat tinggi Siswa SMA Kelas X”.

\section{METODE PENELITIAN}

Metode penelitian yang digunakan adalah penelitian pengembangan (Research and Development) yang mana dalam pengembangnya menerapkan model ADDIE. Penelitian pengembangan dengan model ADDIE menurut I Made Tegeh, dkk. (2014, 41) merupakan singkatan dari setiap tahapannya, yaitu Analyze, Design, Development, Implement, dan Evaluate. Langkah-langkah pada model ADDIE mudah dipahami dan diimplementasikan untuk mengembangkan produk seperti buku ajar, modul pembelajaran, dan multimedia [17]. Model ADDIE memungkinkan dilakukan evaluasi pada setiap tahap pengembangan produk. Hal tersebut dapat meminimalisir kesalahan dan kekurangan produk pada tahap akhir.

Pada tahap analisis (Analyze), dilakukan analisis kebutuhan lapangan, analisis materi, dan analisis teknologi. Pada analisis kebutuhan lapangan, berdasarkan kuesioner yang telah disebarkan kepada 44 responden siswa kelas X MIPA di SMA Negeri 44 Jakarta 95.45\% siswa memerlukan bahan ajar yang dapat digunakan sebagai penunjang pembelajaran mandiri, $88.64 \%$ siswa membutuhkan modul elektronik yang memuat soal-soal untuk meningkatkan kemampuan berpikir tingkat tinggi, $95.45 \%$ siswa membutuhkan modul elektronik pada pokok bahasan momentum dan impuls yang dilengkapi dengan gambar, animasi dan video, dan pada analisis teknologi 100\% siswa mempunyai fasilitas teknologi sebagai penunjang pembelajaran mandiri.

Pada tahap perencanaan (Design), hasil dari tahap analisis kebutuhan digunakan sebagai acuan dalam penyusunan dan pengembangan bahan ajar berupa e-modul, kemudian e-modul fisika untuk pokok bahasan momentum dan impuls ini terbagi menjadi beberapa pembahasan yang penyusunannya mengacu pada model Process Oriented Guided Inquiry Learning (POGIL). E-modul didesain semenarik mungkin baik dari halaman sampul, layout, warna latar halaman, ukuran huruf, jenis huruf, dan warna huruf. Selain itu pada tahap ini ditentukan software yang akan digunakan dalam pembuatan e-modul berbasis Process Oriented Guided Inquiry Learning (POGIL). Software yang digunakan untuk e-modul ini antara lain 3D Page Flip Professional, kuis interaktif dengan applikasi iSpring Quiz Maker, dan Wondershare Filmora Video Editor.

Pada tahap pengembangan (Develop), kegiatan dilanjutkan dengan merealisasikan rancangan produk, yaitu yaitu membuat e-modul berbasis Process Oriented Guided Inquiry Learning (POGIL) untuk meningkatkan kemampuan berpikir tingkat tinggi siswa SMA kelas $X$ dan membuat e-modul sebagai bahan ajar mandiri siswa. Selain itu pada tahap ini dilakukan validasi e-modul oleh ahli materi, media, dan pembelajaran dengan menggunakan instrumen penilaian yang diinterpretasikan dalam Skala Likert.

Pada tahap penerapan (Implementation), Setelah e-modul berbasis POGIL untuk meningkatkan kemampuan berpikir tingkat tinggi siswa melalui uji validasi oleh ahli materi, ahli media, dan ahli pembelajaran, e-modul diujicobakan kepada siswa untuk dapat mengetahui tanggapan siswa mengenai e-

Seminar Nasional Fisika 2019

Prodi Pendidikan Fisika dan Fisika, Fakultas MIPA, Universitas Negeri Jakarta 
modul yang telah dikembangkan, lalu siswa akan mengisi angket untuk mengetahui sejauh mana keefektifan penggunaan e-modul sebagai bahan ajar mandiri. Kemudian setelah e-modul diujicobakan, dilihat pula perolehan nilai pre test dan post test siswa setelah menggunakan e-modul.

Pada tahap evaluasi (evaluation), pada tahap ini produk dievaluasi sebagai bentuk revisi dari hasil uji coba siswa. Apabila dalam uji coba lapangan masih ditemukan kekurangan, maka perlu dilakukan tahap evaluasi, dimana peneliti melakukan penyempurnaan e-modul fisika yang dikembangkan.

\section{Teknik Analisis Data}

Data yang diperoleh dianalisis dengan menggunakan perhitungan berdasarkan skala Likert. Instrumen yang digunakan dalam penelitian ini menggunakan skala Likert dengan pilihan skor 1-5 [18]:

TABEL 1. Skala Likert untuk Penilaian

\begin{tabular}{ccc}
\hline No & Alternatif Jawaban & Bobot Skor \\
\hline 1 & Sangat baik & 5 \\
2 & Baik & 4 \\
3 & Cukup & 3 \\
4 & Kurang baik & 2 \\
5 & Sangat tidak baik & 1 \\
\hline
\end{tabular}

Interpretasi skor dihitung berdasarkan skor perolehan pada masing-masing aspek dengan persamaan:

$$
\text { Interpretasi skor }(\%)=\frac{\sum \text { skor perolehan }}{\sum \text { skor maksimum }} \times 100 \%
$$

Batas penilaian ketepatan dan kesesuaian pengembangan media pembelajaran untuk dijadikan sebagai alat bantu pembelajaran didasarkan pada kriteria interpretasi skor untuk skala Likert:

TABEL 2. Presentase dan Interpretasi Skor untuk Skala Likert

\begin{tabular}{ccc}
\hline No & Presentase & Interpretasi \\
\hline 1 & $0 \%-20 \%$ & Sangat tidak layak \\
2 & $21 \%-40 \%$ & Tidak layak \\
3 & $40 \%-60 \%$ & Cukup layak \\
4 & $60 \%-80 \%$ & Layak \\
5 & $80 \%-100 \%$ & Sangat Layak \\
\hline
\end{tabular}

Besarnya peningkatan kemampuan mengerjakan soal HOTS antara sebelum dan sesudah proses pembelajaran dihitung dengan persamaan gain [19]:

$$
\text { gain ternormalisasi }(g)=\frac{\text { skor posttest-skor pretest }}{\text { skor maksimum-skor pretest }}
$$

Menurut Sundayana (2016), kategori gain (g) sebagai berikut:

Seminar Nasional Fisika 2019

Prodi Pendidikan Fisika dan Fisika, Fakultas MIPA, Universitas Negeri Jakarta 
TABEL 2. Interpretasi Skor Uji Gain

\begin{tabular}{ccc}
\hline No & Presentase & Interpretasi \\
\hline 1 & $-1,00 \leq \mathrm{g} \leq 0,00$ & Terjadi penurunan \\
2 & $\mathrm{~g}=0,00$ & Tidak terjadi Peningkatan \\
3 & $0,00<\mathrm{g}<0,30$ & Rendah \\
4 & $0,30<\mathrm{g}<0,70$ & Sedang \\
5 & $0,70<\mathrm{g}<1,00$ & Tinggi \\
\hline
\end{tabular}

\section{HASIL DAN PEMBAHASAN}

Pada tahap pengembangan modul elektronik, pertama yang dilakukan adalah mengembangkan komponen-komponen yang ada di dalam modul, seperti teks materi, gambar, contoh soal, animasi, audio, video, tes fomatif, dan evaluasi sumatif. Pengembangan ini juga didasari atas studi literatur dari penelitian sebelumnya terkait 3D Pageflip [20-22], agar produk yang dikembangkan memiliki unsur minimal yang lebih baik. Selanjutnya semua komponen yang telah dibuat disatukan menggunakan software flipbook.

Konten modul seperti video dapat diunduh dan disesuaikan dengan kebutuhan isi materi modul. Untuk mempermudah dalam menyampaikan informasi pada video, maka video diedit dengan menggunakan software wondershare filmora 8.3.5.6. Konten lainnya seperti animasi mengunduh file SWF dan gambar pada modul diedit dengan menggunakan software Paint. Pengembangan kuis menggunakan software iSpring Suite 8 yang dihubungkan ke e-mail guru atau fasilitator dengan berbagai tipe soal. Untuk tes formatif dan evaluasi evaluasi menggunakan tipe soal pilihan ganda. Soal pilihan ganda yang telah dikerjakan diberikan umpan balik dan respon terhadap jawaban siswa, sementara untuk hipotesis menggunakan tipe soal essay.

Keseluruhan komponen tersebut, kemudian disatukan pada software 3D PageFlip Professional 1.7.7 menjadi sebuah multimedia pembelajaran berupa e-modul yang memiliki kelebihan seperti tampilan yang sangat menarik, navigasi yang lengkap, efek membalik modul digital lebih nyata, serta tampilan video yang lebih jelas. Berikut ini adalah tampilan modul elektronik fisika yang telah dikembangkan:

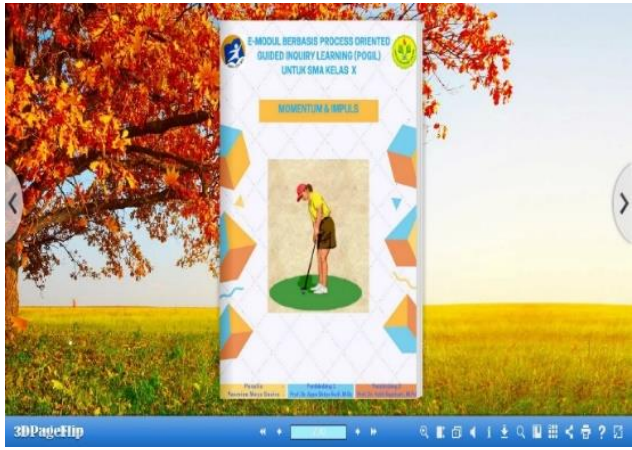

(a)

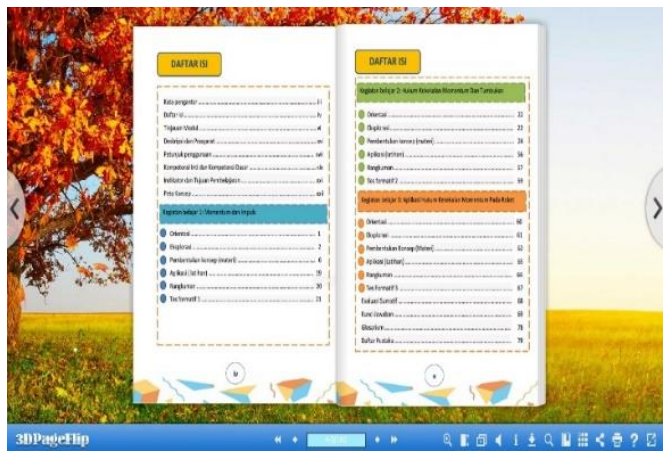

(b)

Seminar Nasional Fisika 2019

Prodi Pendidikan Fisika dan Fisika, Fakultas MIPA, Universitas Negeri Jakarta 


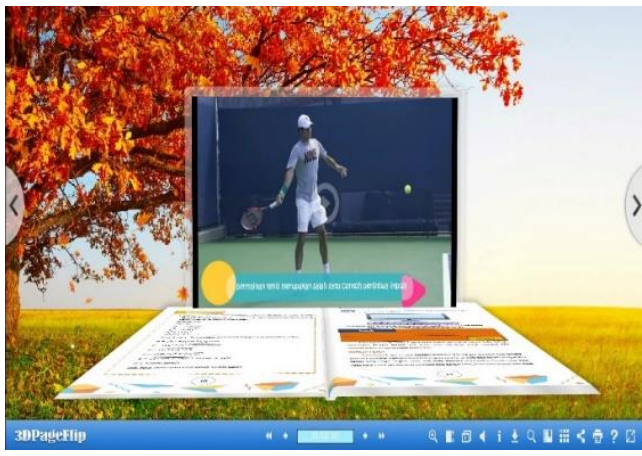

(c)

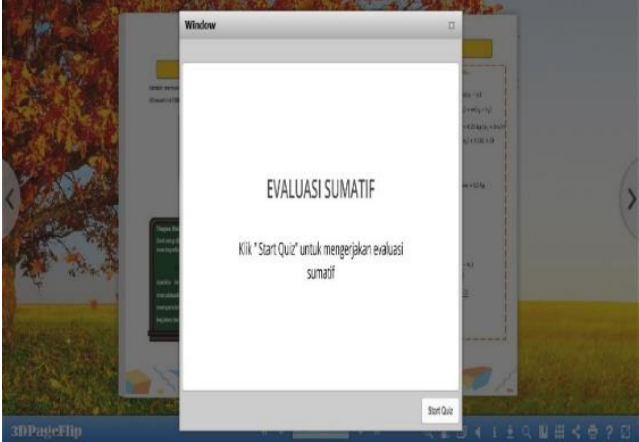

(d)

GAMBAR 1. (a) Tampilan cover depan e-modul, (b) Tampilan daftar isi e-modul, (c) Tampilan video, (d) Tampilan evaluasi sumatif.

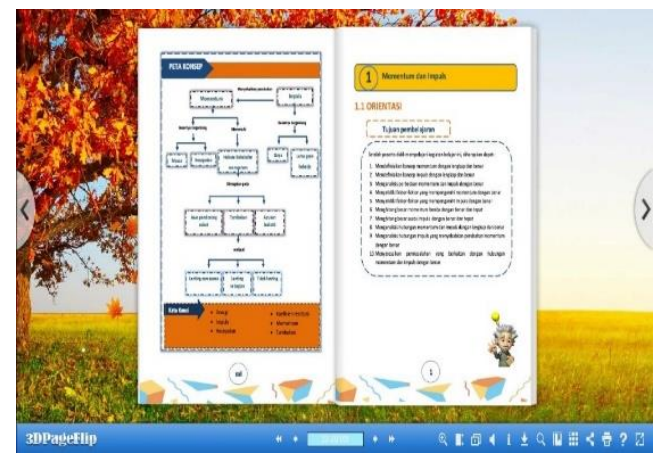

(a)

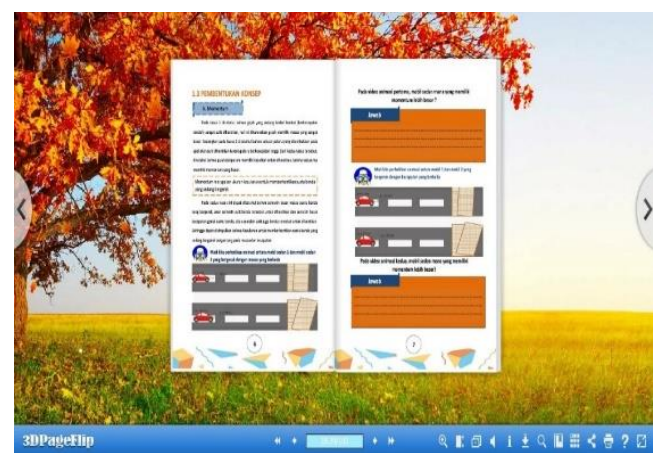

(a)

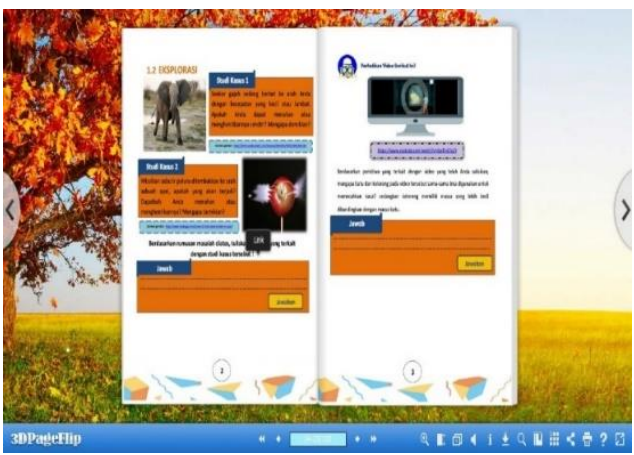

(b)

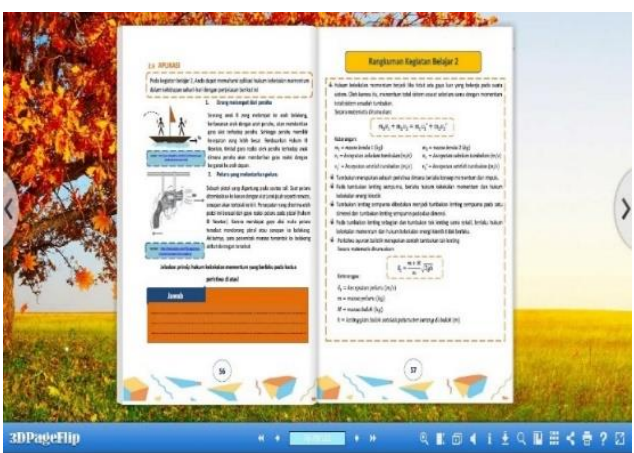

(b)

GAMBAR 2. (a) Tampilan tahap orientasi, (b) Tampilan tahap eksplorasi, (c) Tampilan tahap pembentukan konsep, (d) Tampilan tahap aplikasi.

Uji validasi modul elektronik oleh ahli materi mendapatkan hasil rata-rata persentase kelayakan sebesar $82.78 \%$ dengan kategori sangat layak. Aspek yang diukur oleh ahli materi ialah aspek materi pada struktur modul, aspek karakteristik modul, aspek tahapan model pogil, dan aspek tata bahasa. Aspek materi pada struktur modul diperoleh hasil sebesar $86.67 \%$ dengan kategori sangat layak, aspek karakteristik modul diperoleh hasil sebesar $84.44 \%$ dengan kategori sangat layak, aspek tahapan model pogil diperoleh hasil sebesar $80 \%$ dengan kategori layak, dan aspek tata bahasa diperoleh hasil sebesar $80 \%$ dengan kategori layak. Saran yang diberikan oleh ahli materi adalah perlu diperbaiki konsistensi penulisan persamaan dan periksa kembali bebarapa kalimat. 


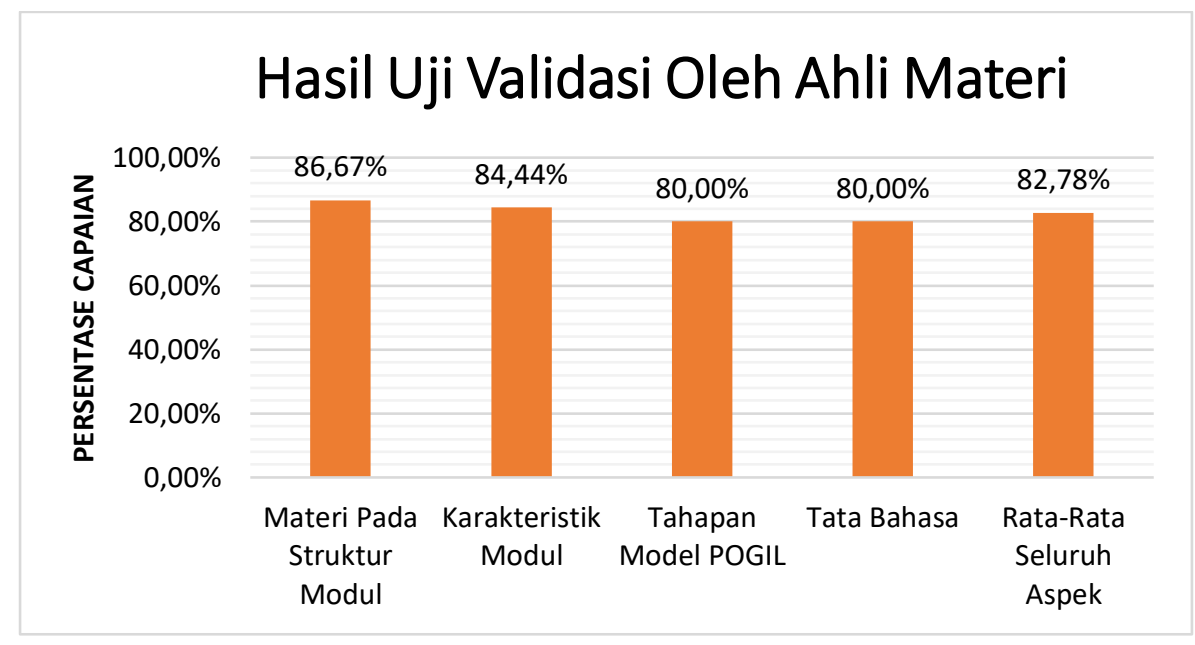

GAMBAR 3. Diagram hasil validasi ahli materi

Uji validasi modul elektronik oleh ahli media mendapatkan hasil rata-rata persentase kelayakan sebesar $88.81 \%$ dengan kategori sangat layak. Aspek yang diukur oleh ahli media ialah aspek karakteristik modul, aspek media pada struktur modul, dan aspek tata bahasa. Aspek karakteristik modul diperoleh hasil sebesar $89.80 \%$ dengan kategori sangat layak, aspek media pada struktur modul diperoleh hasil sebesar $84.62 \%$ dengan kategori sangat layak, dan aspek tata bahasa diperoleh hasil sebesar $92 \%$ dengan kategori sangat layak. Saran yang diberikan oleh ahli media adalah tujuan pembelajaran revisi, harus terdapat teknik atau pendekatan yang dapat dilaksanakan pada kegiatan belajar untuk mencapai kompetensi yang diharapkan pada kurikulum.

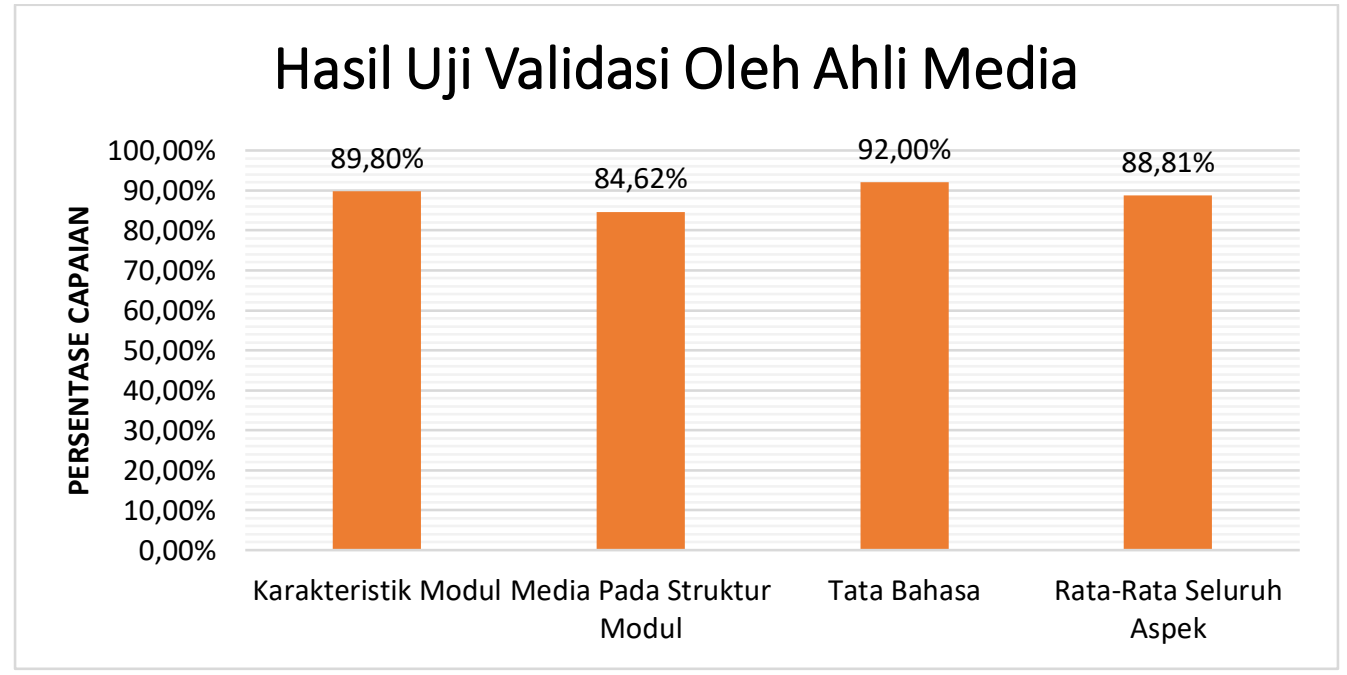

GAMBAR 4. Diagram hasil validasi ahli media

Uji validasi modul elektronik oleh ahli pembelajaran mendapatkan hasil rata-rata persentase kelayakan sebesar $80.83 \%$ dengan kategori sangat layak. Aspek yang diukur oleh ahli pembelajaran ialah aspek materi pada struktur modul, aspek tahapan model pogil, dan aspek tata bahasa. Aspek materi pada struktur modul diperoleh hasil sebesar $82.50 \%$ dengan kategori sangat layak, aspek tahapan model pogil diperoleh hasil sebesar $80 \%$ dengan kategori layak, dan aspek tata bahasa diperoleh hasil sebesar $80 \%$ dengan kategori layak. Saran yang diberikan oleh ahli pembelajaran adalah perbaiki tujuan 
pembelajaran, harus terdapat gambar untuk memperkuat konsep, disediakan rangkuman materi, dan soal mengacu pada kompetensi dasar.

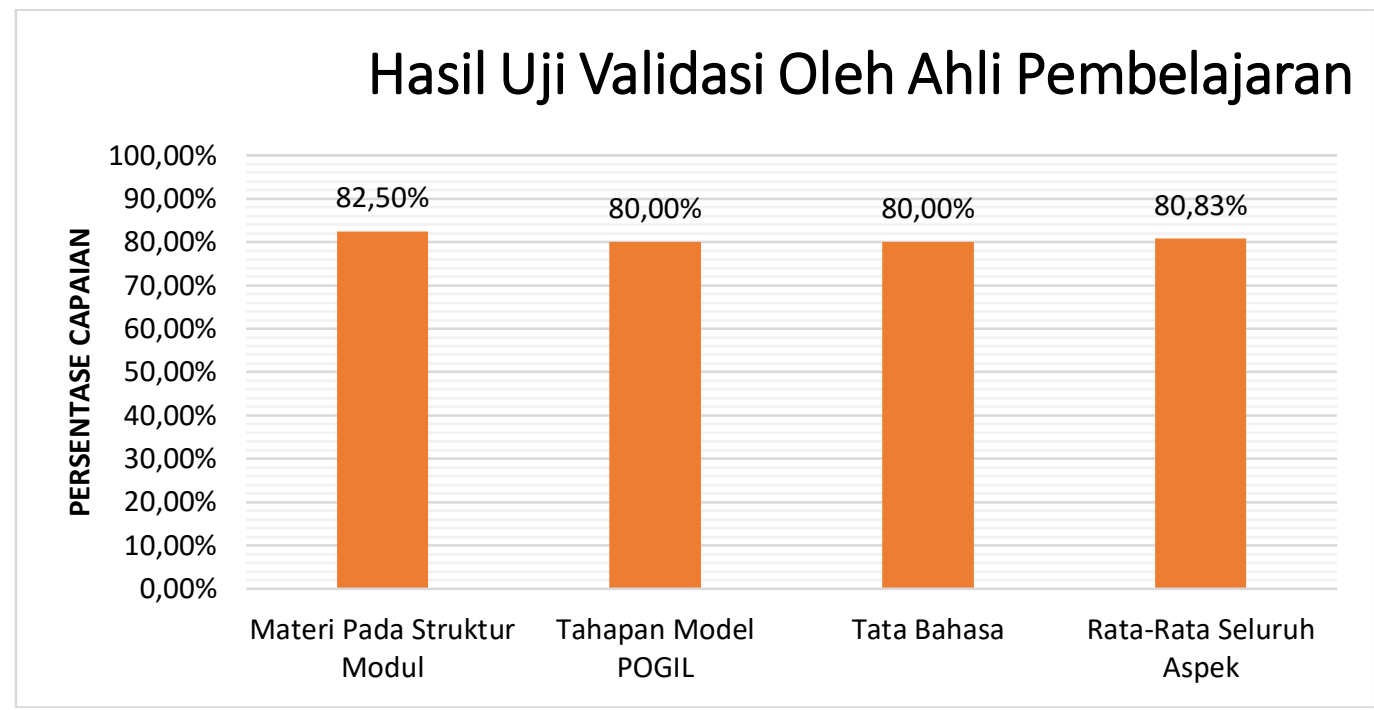

GAMBAR 5. Diagram hasil validasi ahli pembelajaran

Hasil uji coba lapangan oleh guru fisika SMA mendapatkan hasil rata-rata persentase kelayakan sebesar 98.25\% dengan kategori sangat layak. Aspek yang diukur oleh guru fisika SMA ialah aspek materi pada struktur modul, aspek tahapan model pogil, aspek karakteristik modul, dan aspek tata bahasa, Aspek materi pada struktur modul diperoleh hasil sebesar $100 \%$ dengan kategori sangat layak, aspek tahapan model pogil diperoleh hasil sebesar $97.5 \%$ dengan kategori layak, aspek karakteristik modul diperoleh hasil sebesar $95.5 \%$ dengan kategori sangat layak, dan aspek tata bahasa diperoleh hasil sebesar $100 \%$ dengan kategori sangat layak. Saran yang diberikan oleh guru fisika SMA adalah penempatan gambar mohon diperhatikan kembali.

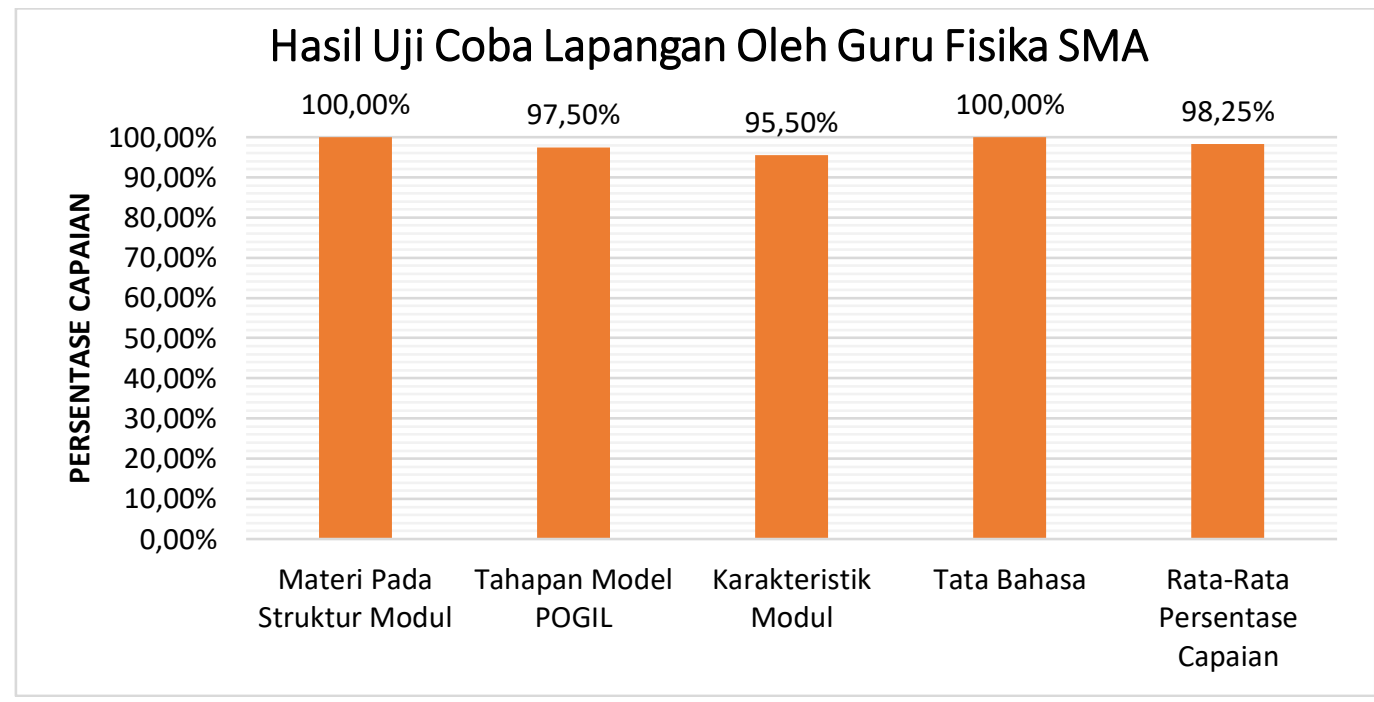

GAMBAR 6. Diagram Hasil Uji Coba Lapangan Oleh Guru Fisika SMA 
Hasil uji coba lapangan oleh peserta didik mendapatkan hasil rata-rata persentase kelayakan sebesar 92.05\% dengan kategori sangat layak. Aspek yang diukur oleh peserta didik ialah aspek materi pada struktur modul, aspek karakteristik modul, dan aspek tata bahasa, Aspek materi pada struktur modul diperoleh hasil sebesar $88.13 \%$ dengan kategori sangat layak, aspek karakteristik modul diperoleh hasil sebesar 95.06\% dengan kategori sangat layak, dan aspek tata bahasa diperoleh hasil sebesar 92.97\% dengan kategori sangat layak.

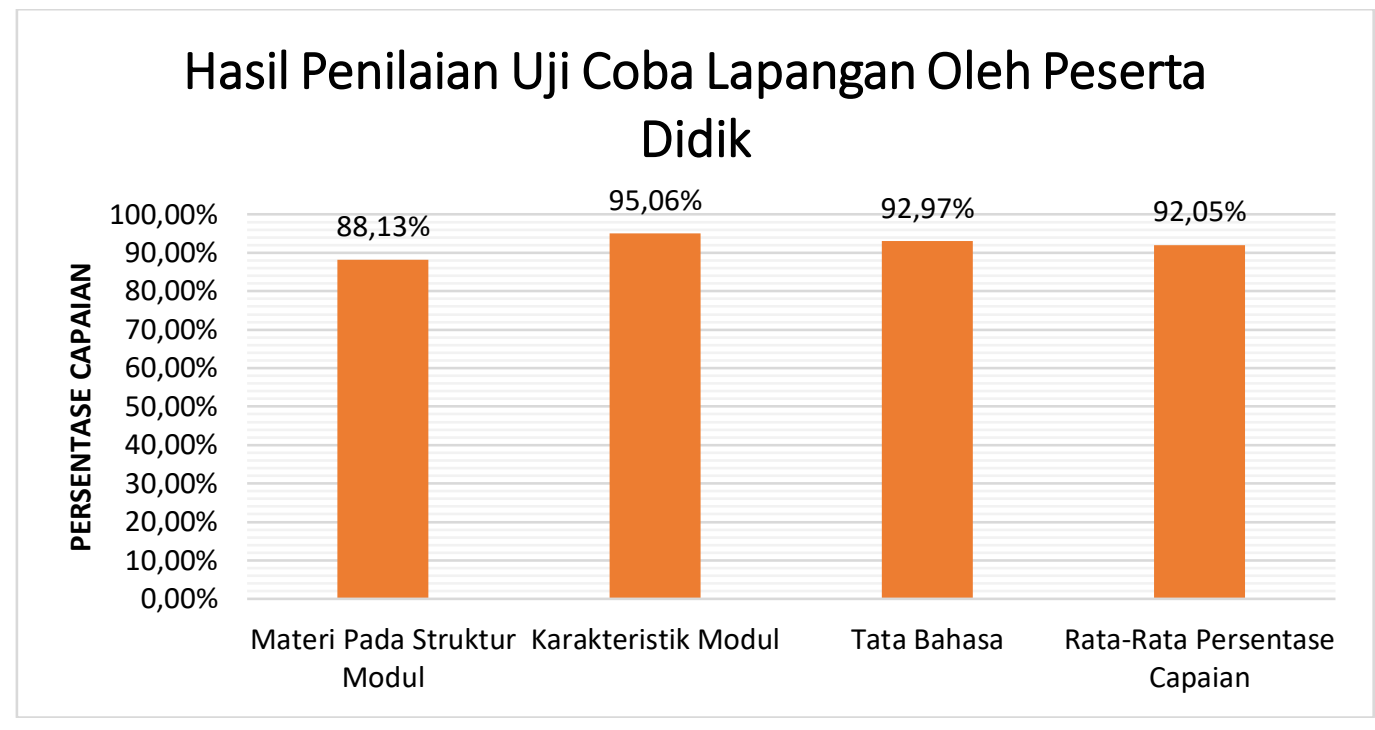

GAMBAR 7. Diagram Hasil Uji Coba Lapangan Oleh Peserta Didik

\section{SIMPULAN}

Berdasarkan hasil uji validasi oleh ahli materi, ahli media, dan ahli pembelajaran, serta hasil uji coba lapangan oleh guru fisika dan peserta didik dapat disimpulkan bahwa e-modul materi momentum dan impuls berbasis process oriented guided inquiry learning (pogil) yang telah dikembangkan layak dijadikan bahan ajar mandiri untuk meningkatkan kemampuan berpikir tingkat tinggi siswa SMA Kelas X.

\section{UCAPAN TERIMA KASIH}

Terimakasih kepada Prodi Pendidikan Fisika dan Prodi Fisika FMIPA UNJ serta dosen-dosenyang telah membimbing untuk menyelesaikan penelitian pengembangan ini. Terima kasih juga kepada Bapak Teguh Budi Prayitno, M.Si selaku ahli materi, Ibu Dwi Susanti, M.Pd selaku ahli media, dan Bapak Prof.Dr. I Made Astra, M.Si selaku ahli pembelajaran yang telah bersedia memvalidasi serta memberikan saran agar produk yang dikembangkan menjadi lebih baik.

\section{REFERENSI}

[1] Kemendikbud, Kompetensi Dasar Sekolah Menengah Atas/ Madrasah Aliyah, Jakarta: Kementerian Pendidikan dan Kebudayaan, 2013. 
[2] M. S. Zuhri dan Jatmiko, "Penerapan Model Pembelajaran Inkuiri Menggunakan phET Simulation Untuk Menurunkan Miskonsepsi Siswa Kelas XII pada Materi Fluida Statis di SMAN Kesamben Jombang," Jurnal Inovasi Pendidikan Fisika, Vol.3, 2014, pp.103-107.

[3] Daryanto, Media Pembelajaran, Yogyakarta: Gava Media, 2017.

[4] R.A. Sani, Inovasi Pembelajaran, Jakarta: Bumi Aksara, 2013.

[5] M. Kuswandari, W. Sunarno, dan Supurwoko, "Pengembangan Bahan Ajar Fisika SMA dengan Pendekatan Kontekstual Pada Materi Pengukuran Besaran Fisika," Jurnal Pendidikan Fisika, Vol. 1, No. 2, 2013, pp. 41-44.

[6] T. Woo, "Developing Quality Learning Materials for Effective Teaching and Learning in an ODL Environment: Making The Jump From Print Modules to Online Modules," AAOU Journal. Vol 6, No.1, pp. 53-55, 2011.

[7] I. Suarsana and G. Mahayukti, "Pengembangan E-modul Berorientasi Pemecahan Masalah," Jurnal Pendidikan Indonesia, Vol. 2, No. 2, p. 266, 2013.

[8] A. Rahim, Jufrida, and S. Nova, "Pengembangan Modul Elektronik Berbasis Discovery Learning Menggunakan 3D Pageflip Professional Pada Materi Gerak Lurus untuk Kelas X SMA," Skripsi, Universitas Negeri Jambi, p. 10, 2017.

[9] A. D. Sutrisno, "Model Pembelajaran Two Stay Two Stray dan Pemahaman Siswa Tentang Konsep Momentum dan Impuls," Jurnal Pengajaran MIPA, Vol. 1, No. 20, pp. 38-42, 2015.

[10] A. Kurniawan, "Penerapan Model Pembelajaran Inkuiri Terbimbing Berbantuan CMAPTOOLS dalam Pembelajaran Fisika Untuk Meningkatkan Kemampuan Kognitif dan Mempertahankan Rerensi Siswa," Jurnal Penelitian Pendidikan, Vol. 14, No. 1, pp. 17-26, 2014.

[11] L. Khasyytillah, Yennita, and M. Irianti, "Pengembangan Lembar Kerja Siswa Higher Order Thinking Skills (HOTS) Pada Materi Momentum, Impuls, dan Tumbukan SMA Kelas XI/Semester 1," Jurnal Online Mahasiswa FKIP, Vol. 3 No. 2, 2016.

[12] D. K. Agustin, "Kesalahan Siswa SMA dalam Memecahkan Masalah Momentum Impuls," Prosiding Seminar Nasional Pendidikan IPA, Vol. 1, pp. 174-183, 2016.

[13] M. Huda, Model-model Pengajaran dan Pembelajaran, Yogyakarta: Pustaka Belajar, 2014.

[14] M. J. Barthlow, The Effectiveness Of Process Guided Inquiry Learning To Reduce Alternate Conception In Secondary Chemistry. Lynchburg: Liberty University, 2011.

[15] I. Bilgin, and Geban, "The Effects Of Guided Inquiry Instruction Incorporating A Cooperative Learning Approach On University Student's Achievement Of Acid And Bases Concepts And Attitude Toward Guided Inquiry Instruction," Sci Res \& Essay, Vol. 4, No. 10, pp. 1038-1046, 2009.

[16] C. Retno, "Pengembangan E-Module Kimia Berbasis Pogil (Process Oriented Guided Inquiry Learning) Pada Materi Reaksi Reduksi-Oksidasi Sebagai Sumber Belajar Siswa,” 2017.

[17] I. M. Tegeh, I. N. Jampel and K. Pudjawan, Model Penelitian Pengembangan, Jogjakarta: Graha Ilmu, 2014.

[18] Riduwan, Skala Pengukuran Variabel-variabel Penelitian, Bandung: Alfabeta, 2013.

[19] R. Sundayana, Statistika Penelitian Pendidikan, Bandung: Alfabeta, 2016.

Seminar Nasional Fisika 2019 
[20] S. Syahrowardi and A. H. Permana, "Desain Handout Multimedia Menggunakan 3D Pageflip Professional untuk Media Pembelajaran pada Sistem Android", Jurnal Penelitian dan Pengembangan Pendidikan Fisika, vol. 2, no. 1, 2016, pp. 89 - 96.

[21] H. Kurniawati, D. Desnita, and S. Siswoyo, "Pengembangan Media Pembelajaran Berbasis 3D PageFlip Fisika untuk Materi Getaran dan Gelombang Bunyi", Jurnal Penelitian dan Pengembangan Pendidikan Fisika, vol. 2, no. 1, 2016, pp. 97 - 102.

[22] F. Bakri, B. Z. Siahaan, and A. H. Permana, "Rancangan Website Pembelajaran Terintegrasi dengan Modul Digital Fisika Menggunakan 3D PageFlip Professional", Jurnal Penelitian dan Pengembangan Pendidikan Fisika, vol. 2, no. 2, 2016, pp. 113 - 118. 